\title{
UNDERSTANDING LOCAL GOVERNANCE: an international perspective
}

Robert H. Wilson

Philips International Visiting Professor at the EAESP/

FGV, Mike Hogg Professor of Urban Policy at LBJ School of Public Affairs and Director of the Urban Issues Program at the University of Texas at Austin. E-mail: rwilson@mail.utx.edu

\section{RESUMO}

Grandes mudanças e inovações estão ocorrendo nas práticas governamentais no mundo todo. Governança local, particularmente, tem sido uma preocupação em muitos países. Processos como redemocratização e descentralização e imposições das agências internacionais têm se concentrado no desenvolvimento de boas práticas de governança. Melhoria em governança local permanece uma alta prioridade na maior parte dos países, mas, a menos que a relação entre cidadãos e governo seja mais desenvolvida completamente, as ações do governo local não levarão, necessariamente, à melhoria nas condições de vida das pessoas. Este artigo explora o conceito de governança e propõe um instrumento analítico para o estudo de governança local em um contexto internacional.Ele termina apresentando recomendações sobre as estratégias para melhorar os sistemas de governança e o desempenho governamental.

\section{ABSTRACT}

Enormous change and innovation in governmental practices are occurring throughout the world. Local governance, in particular, has become a concern in many countries. Processes such as redemocratization and decentralization and imperatives of international lending agencies have focused attention on developing good governance practices. Improvement in local government remains a high priority in most countries, but unless the relationship between citizens and government is more fully developed the actions of local government will not necessarily lead to improvement in the conditions of people's lives. This paper will explore the concept of governance and propose an analytical framework for the study of local governance in an international context. The article concludes with recommendations on strategies to improve governance systems and government performance.

\section{PALAVRAS-CHAVE}

Desempenho governamental, sociedade civil, decentralização, governança local, redemocratização.

\section{KEY WORDS}

Government performance, civil society, decentralization, local governance, redemocratization. 
UNDERSTANDING LOCAL GOVERNANCE: AN INTERNATIONAL PERSPECTIVE

Enormous change and innovation in governmental practices are occurring throughout the world. Local governance, in particular, has become a concern in many countries. Processes such as redemocratization and decentralization and imperatives of international lending agencies have focused attention on developing good governance practices. The interest in governance represents, in part, a response to the recognition that improvement in the capacity of government is not, by itself, sufficient to insure better outcomes from government actions. Improvement in local government remains a high priority in most countries, but unless the relationship between citizens and government is more fully developed the actions of local government will not necessarily lead to improvement in the conditions of people's lives. This paper will explore the concept of governance and propose an analytical framework for the study of local governance in an international context.

Governance has come to be used as a normative proposition, as will be discussed below. The characteristics associated with good governance include free and open elections, the rule of law with the protection of human rights, citizen participation, transparency and accountability in government, among others. For those interested in government practice, these normative values and goals are helpful. In this paper, however, we will use the concept of governance to structure a diagnostic framework for identifying and understanding the causes of poor governance in particular contexts.

The framework and discussion focus on issues of governance at the local level. This level of analysis is chosen for two principal reasons. A process of political and administrative decentralization is underway in many countries of the world and this process invariably places new responsibilities on local government. In addition, the direct interaction among citizens and government is most visible at the local level.

This paper will first explore the emergence of governance as a prominent question. A definition and analytical framework for evaluating governance will be presented. The two principal elements of the framework, civil society and government capacity, will be discussed in detail. The paper then considers the means by which citizens influence local government. A discussion of the challenges to improving local governance concludes the paper.

\section{Why governance?}

Governance has gained great currency during the last decade. The concept emerged in a specific historical context but is now utilized for a multitude of purposes. The evolution in the approach to development among the major international organizations set the context in which governance would become prominent. A commonly accepted focus on institutional development gave way to management development in the 1980s. This view continued to rely on a largely state-led strategy of development, but the concern with the management of governmental organizations represented an important change in view. Discussions of broader issues of management meant that the political and social context of state led development received attention. In addition the confluence of decentralization, as one element of structural adjustment policies, and of demands for redemocratization in many countries forced a shift in focus from government itself to the means by which government manages and utilizes resources.

A clear articulation of this significant shift can be found in the World Bank's analysis of the lack of progress in Africa (World Bank, 1989, 1994). Various weaknesses in governmental institutions, including corruption, lack of accountability, and denial of human rights, created conditions which prevented or impeded development. Improvement in governance, therefore, was viewed as an enabling condition for successful development. The World Bank offered a definition of governance as the exercise of political power in the management of a country's affairs. In a later publication, the emphasis on the term governance continued to be placed on the management of a country's economic and social resources for purposes of development (World Bank, 1992, p. 3). The Bank's mandate prevents involvement in country politics. But the 
political dimension of governance could be addressed through a focus on the process by which authority is exercised and on capacity of institutions.

The World Bank's definition drew substantial criticism (Leftwich, 1993; Hyden, 1992). Some argued that it was no more than an attempt to impose a Western liberal democratic model on the developing countries. Others argued that it poorly disguised a neoliberal view of the public sector that essentially argues for leaner and more efficient government and one consistent with the needs for capitalist development.

In spite of the World Bank's management orientation, by placing a high priority on governance issues, the Bank invited attention on the nongovernmental dimensions of effective governmental action. The concept shifted attention from an exclusive focus on state-lead development and provided a clear justification to examine democratic practices, needs of excluded populations, and other neglected issues. These differing conceptions of governance generated substantial debate and a consensus on a definition has yet to emerge.

In addition to competing conceptions of governance, the formation of a consensus faces the challenge that the term does not fare well in translation. No suitable translation of governance exists in Spanish and Portuguese (Ziccardi, 1995). The closest approximation, "governability," is concerned with the exercise of public power in governmental action but incorporates various conditions necessary for efficient action. These conditions include the legitimacy of government and society's support of it. In democratic regimes, legitimacy is fundamentally dependent on fair, free, and contested elections but elections, however, are not sufficient for creating legitimacy of governmental action. ${ }^{1}$

The difficulty of reaching a satisfactory and operational definition of governance has led to an emphasis on the normative dimension of the concept and the identification of the characteristics of good governance (McCarney, 1996). Although likely to be culturally based and thus vary among countries, these characteristics include transparent and accountable government, respect for human rights, democracy, rule of law, fair and accessible judicial systems, and independent news media, among others. In some countries, decentralization of central authority to local governmental institutions is viewed as a condition for good, or improved, governance. By focusing on the normative dimension of governance and identifying characteristics of good governance, strategies or methods for improving governance emerge.

\section{Governance refers to the interaction between civil society and government in determining governmental action.}

This rich literature demonstrates the elasticity of governance as a concept. One may wish to embrace this elasticity or declare the concept of governance too ambiguous to be of practical value. In any case, the debate has clearly encouraged policymakers to look beyond government itself for evaluating the efficiency and appropriateness of governmental action.

Following the suggestion of Halfani et al., this paper will work with a concept of governance that places emphasis on the nature of the relationship between rulers and the ruled, the state and the society, the government and the governed (McCarney, Halfani and Rodriguez, 1995). Governance, according to this usage, refers to the interaction between civil society and government in determining governmental action. By civil society, we refer to those organized segments of society outside the public sector, including the civil associations, community organizations, social movements, trade unions, religious organizations, among others. Governmental action is broadly construed to include public sector investments, implementation of social and economic development programs, operations of governmental institutions, and operations of judicial systems; in sum, actions taken by public sector institutions. Although government or government-designated actors 
are undertaking the actions, decisions concerning which actions to take result from the interaction of government and civil society.

The concept of governance used here gives emphasis to the relation or interaction between civil society and government. The wide variety of specific types of interaction can be classified in two broad categories: formal and informal relationships. Formal relationships refer to legal and institutional processes including the protection of human rights, rule of law, election systems, and formal mechanisms of accountability. The taxation system constitutes one type of formal link between civil society and government. The existence of these types of formal relationships may guarantee the existence of a procedural democracy but one that may not effectively incorporate all segments of the population (Dahl, 1989). Informal mechanisms of interaction include political culture, political parties, the media, openness in government operations, venues for discussion of common issues and the formation of informed opinion.

The existence of various types of formal and informal relationships does not themselves guarantee good governance. The press may not be independent of government influence, political parties may not serve as a vehicle for the articulation of public interest, and elections may not be free or fair. The nature and quality of interaction will depend not only on the existence of formal and informal relationships, but also on conditions in civil society and on the capacity of government to perform. With regard to civil society, the degree of organization in a society, the so-called level of social capital, conditions governance. Weakly organized civil societies face difficulties in articulating social priorities and demands and will likely lack the means to influence government action. With regard to government, the lack of capacity to act effectively reduces the quality of governance regardless of the degree of organization in civil society. A weakly organized society or an incapable government can constrain the interaction between the two, and thus lead to ineffective government action.

This definition and conception of governance encounters at least one serious shortcoming. In what sense can one realistically separate civil society and government? Our discussion here distinguishes between institutions in the public sector and organizations outside the public sector. This boundary, however, is problematic for theoretical and operational reasons. In Plato's conception, the republic was the embodiment of civil society, not in tension with it. Even though later liberal theorists, such as Hobbes and Locke, became concerned with the coercive power of the state and mechanisms to constrain it, government was still a creation of society. Members of government are also members of society. A citizen that assumes a function in government does not lose his or her role in civil society or civil organizations. Elected officials are members of governmental institutions, but they may also remain members of a variety of civil organizations. In addition, these elected officials may be representing the interests of civil society in their elected capacities. This issue becomes particularly acute when examining local governance, especially in relatively small communities where governmental officials may have a greater loyalty to local communities than to governmental institutions. The institutional demarcation of government and civil society may appear quite distinct, but in contexts where institutions are relatively weak and citizen affiliations multifaceted, the demarcation may be quite fuzzy.

Our proposed conception of governance follows the common practice of using government rather than the concept of the state. Given the overlap of these two concepts, the justification for using government needs to be explored. In recent years, the renewed interest and use of the concept of state in academic research have reflected a move from the previously prevailing society-centered studies (Skcopol, 1985). Building on the Weberian tradition of the concept, Peter Evans writes: "The state must be considered more than the 'government'. It is the continuous administrative, legal, bureaucratic and coercive systems that attempt not only to structure the relationships between civil society and public authority in a polity but also to structure many crucial relationships within civil society as well" (Stepan, 1978).

The concept of the state joins governmental and nongovernmental actors into systems that serve various purposes. The concept of state recognizes that individuals or narrow groups in civil society can exercise great control, through 
systemic mechanisms, over governmental action. In spite of this important observation, our use of the more narrowly defined category of government allows an institutionally-based focus on government agencies as actors and producers of outcomes. However, the process by which decisions on governmental action are made will look toward actors and institutions in government and in civil society. In other words, our framework is sufficiently flexible to recognize that some elements of the civil society-government relationship will be systematic and can be used to exercise control over segments of civil society.

In spite of these conceptual difficulties with boundaries and definitions, distinguishing between civil society and government and examining the relation between the two provide a rich analytical structure that has relevance for many different country settings. Although one may tend to emphasize a one-way connection between civil society and government - that is in democratic societies, societal needs and demands are expected to induce government action - the interaction is indeed two ways. Government action can impede or facilitate the articulation of common demands and interests in civil society. In other words, governmental institutions may be able to shape or limit the demands of public. In addition, the unintended consequences of past government action itself may create new needs in the society.

Even the approach taken in policy design and government action can create the context for defining the role of the citizen if not for defining citizenship itself. For example, a public policy orientation that focuses on rights implies that the role of the citizen should be to promote the incorporation of rights in the law, in the first instance, but that once these rights are established, the role of the citizen becomes one of a consumer of government services to protect these rights. A deliberative policymaking approach, by contrast, envisions citizens as active participants in the policy process rather than consumers (Landy, 1993).

Historical studies have argued that past governmental action can have a decisive impact on the way societies organized themselves politically (Skocpol, 1985, p. 25-27.). Western European countries with historically strong centralized governmental institutions produced a class-based political culture. The highly fragmented and territorial based governmental structure in the United States produced a political culture composed principally of narrowly based interests.

In discussing governance in an international context, the importance of the level of economic development as a conditioning factor, for both

\section{With regard to civil society, the degree of organization in a society, the so-called level of social capital, conditions governance.}

civil society and government capacity, becomes evident. In many of Africa countries and in at least some regions in all countries, widespread and intensive poverty severely constrains the degree of organization in civil society and limits the resources - financial, human, and institutional - available to the public sector, especially in local government. Even in more highly developed countries, pockets of urban or rural poverty limit the opportunities for effective local governance. Inadequate or unsatisfactory governance may be the result of extreme poverty.

Defining governance as an interaction and process creates measurement problems. We cannot easily assess, especially in terms of quantitative measures, whether local governance in a particular country is strong or weak. Nevertheless, this definition does provide a useful framework for considering the effectiveness of local government and citizen participation in it. Unsatisfactory governance, according to this framework, can result from weak organization in civil society, lack of capacity in government, or the interaction of the two. This conception of governance provides a framework for analyzing public sector performance at the local level.

\section{Organization in civil society}

People associate for many different reasons. Common concerns or interests can originate in religion, tribe, race and ethnicity, geography, 
and class, among others. Perhaps the most prominent type of association for communal activities are religious organizations, but individuals participate in political parties, occupational associations, business groups, philanthropic and social organizations, athletic clubs, schools, neighborhood associations, and many others. Regardless of the primary motivation, such groups or associations can connect an individual to the broader society by providing the values and norms which help individuals understand and interpret society and act in it. Gatherings of individuals provide an opportunity for casual conversation concerning the day's events and fostering shared values about a society. Through continual, face-to-face interactions, community problems are defined, solutions are proposed, and consensus is reached. In this sense, associations can serve a mediating function, linking the individual to larger society, and provide a mechanism by which individuals can engage in political life.

Traveling in the United States in the midnineteenth century, the French observer, De Tocqueville, found that the extensive participation of Americans in a wide range of associations made a fundamental contribution to American democratic practice and its likely survival (Tocqueville, 1966). Even though his observation was inspired by a conservative philosophical position, by which organizations and associations constrain government and promote stability, he found such organizations an important vehicle for political expression. The recent redemocratization processes in many countries, which have frequently displaced military dictatorships, have often been led by politically oriented associations, including social movements, voluntary organizations, and citizen associations.

In Robert Putnam's words, associations are social structures of cooperation which provide avenues for groups to pursue common objectives (Putnam, 1993, p. 89-91). Participation in these groups can instill a sense of responsibility for communal action. Through associations common interests can be articulated and aggregated. In societies with large numbers of organizations, multiple membership is likely to occur, thus creating networks of people and organizations. Where such organizations and networks are plentiful, one can speak of civil society being highly organized and having high levels of social capital (Coleman, 1990). These associations and networks allow members to be more efficient and productive, just as physical capital allow workers to be more efficient.

Putnam attempts to determine the effect on government of social organizations by contrasting regions in Italy with different levels of social capital, a point that will be further discussed below (Putnam, 1993). Here our discussion will focus on the effect government can have on the level of social capital. Government and public policy contribute to the enabling environment of social organization. Protection of human rights and the freedom of association are critically important to the ability of social organizations to participate in public life, at least within democratic societies. Charles Taylor defines stages of civil society that depend critically on the state (Taylor, 1990). For civil society to exist, at its most basic level, associations have to be able to coalesce outside the purview of the state. At the next stage, associations have to be permitted to act collectively, and in the most advanced stage, associations must have access to political processes and have sufficient capacity to influence policy outcomes.

But the enabling environment is not the unique determinant of the level of social capital. There are many cases where societies have lost social capital. In the United States, it is argued that a process of deterioration of associational life is leading to the erosion of a wide range of institutions, from family to church to community, weakening society and creating instability. ${ }^{2}$ In the Philippines and Brazil, levels of social capital atrophied under military dictators. In both countries, however, the societies reorganized themselves, in the People's movement in the Philippines and broad popular mobilization in Brazil, to resist the dictatorships and recreate democratic forms of government. In an extreme case, the civil war and collapse of a national government in Lebanon destroyed social capital that is only today being recreated.

Political parties are a critical element of civil society, but their roles may be difficult to analyze. A political party, in theory, should embody the interests and values of its members. In many of the recent movements for redemocratization, political parties exercised 
key leadership. However, in looking broadly across countries, parties assume many different roles. Even within a single country, parties may have differing effects on civil society organization. Rather than articulating and aggregating the interests of their members, parties may serve principally the interest of politicians and be largely organized around electoral needs. In Latin America and elsewhere, parties are often viewed as the embodiment of clientelism and organized around the exchange of favors. Some political parties are indistinguishable from government, especially in one party countries, and as such may impede the development of social organizations outside the purview of the state. Although political parties cannot be entirely indifferent to interests of citizens that belong to them, they may not be effective vehicles for articulating the desires of citizens in some countries.

The objectives of political parties are clearly linked to influencing governmental action. But many associations in civil society may not be interested in the actions of government. Whether associations are politically-oriented or not, an interesting question arises as to how a change in the level of social capital in a country comes about. Why do different levels of social capital exist across countries and even within a single country? Why do some social settings generate large numbers of social organizations? What factors can cause the degree of social organization to change in a country? These are challenging questions. For social capital to play a constructive role in governance, some associations must be concerned with affecting governmental action. If there are few, how can their numbers be increased? Some would argue that political organizations must be created around the interests of people, e.g. the Industrial Areas Foundation in the Southwestern United States ${ }^{3}$ or the Workers' Party in Brazil. Fox argues that government can help create a conducive environment for the growth of social capital through the expansion and guarantee of the political franchise, but that a more productive strategy lies in the creation of horizontal linkages of community and citizen-based organizations in a country (Fox, 1996).

A rather extraordinary phenomenon, operating virtually worldwide, has been the dramatic growth of nongovernmental organizations (NGOs). These organizations can be important actors in the political process but may also provide public services. The restrictions placed on political parties in authoritarian countries have funneled political activism into NGOs, as in Indonesia (Porio, 1996, p. 75). Although these organizations would typically be classified as associations in civil society, they may undertake activities traditionally considered government functions,

\section{Local government provides services to citizens, but citizens have limited opportunity to influence local government and, consequently, the governance relation is ineffective.}

even at times under contract with government agencies. In many developing countries, the identification of NGOs as potential service providers by international agencies is commonly practiced.

\section{Capacity of local government}

Governance has been conceived as the relationship between civil society and government in determining governmental action. If government does not have the capacity to act, the question of governance is moot. Although this point may seem gratuitous and, at best, appropriate in only extreme cases, when addressing local government the point has broad application. In many countries of the world, especially in parts of Africa but in rural areas of developing and developed countries, the capacity of local government to act may be severely lacking. Local governments are frequently illprepared to assume responsibilities for 
policymaking, resource mobilization and program implementation.

Even in instances where local government capacity exists, the governance relationship may be ineffective. Centralized governments may have effective administrative capacity at the local level, but decisions concerning actions of local government may be made by higher levels of government. The relationship between civil society and government at the local level, consequently, is uni-directional; local government provides services to citizens, but citizens have limited opportunity to influence local government and, consequently, the governance relation is ineffective.

In the 1980s, structural adjustment policies in many developing countries were accompanied by an emphasis on managerial orientation for local governments, which reinforced a technical orientation to policy development (Halfani, 1996, p. 183-186.). The management orientation held the potential for improved government action over the earlier, relatively inflexible, administrative orientation. Local problem solving and locally determined deployment of resources were promising developments.

Although the management orientation represented an innovation to local government in many countries, the notion that government should lead the development process was widely held in many developing countries. The concept of government, or the state, as a neutral forum for resolving conflict, a view predominate in several industrialized countries, was found inappropriate in most developing countries. Rather in countries with relatively low levels of development and limited productive resources, the national state often provided the dynamic leadership believed necessary for development. In developing countries, policymaking and government action often became centralized, based on the pragmatic position that efficiency would be gained in the centralized management and application of scarce resources for infrastructure and other investments. The stagnation of the import substitution model in some developing countries engendered great criticism and generated alternative strategies such as neo-liberal development policies.

The call to diminish the role of government in the economy has been accompanied by proposals to decentralize it. Decentralization is seen as a way to make government smaller and more effective and promote democratic practice. Many countries have adopted decentralization policies and the difficulties generated by these policies have called attention to the question of capacity in local government. In countries like Mexico, Brazil, and India, local governments, lacking adequate financial, human, and institutional resources, have frequently not been prepared to assume the new responsibilities required by decentralization. The degree of preparation of local government varies substantially from country to country and even within various regions of the same country (Urban, 1994/1995, Approaches, 1997). But the capacity of local government is a recurring problem in most countries undergoing decentralization. Efforts for administrative reform and the training of individuals to assume positions in local government are critical.

Effective local government action does not depend exclusively on its own administrative capacity. The intergovernmental dimension of government action has become a prominent issue. Local governments are linked to higher levels of government in several different ways, including through constitutional and statutory frameworks, fiscal relations, joint responsibilities of program implementation, and politically. The specific set of linkages varies substantially across countries. The promise of decentralization, in which relatively rigid centralized systems would devolve powers and cooperate with lower levels of government, has proven difficult to fulfill in practice. In the United States, for example, even though the 1970 s and 1980s witnessed significant decentralization of power from the federal government to state government, federal control over states increased significantly in the realm of regulation (Advisory, 1984; Wilson, 1998). Decentralization holds the potential for improved local government action, but local governments operate within a set of complex intergovernmental relations that can constrain if not impede their actions.

Central governments have, for sound and unsound reasons, not encouraged fiscal autonomy of lower level governments. Given the greater efficiency in national systems for revenue collection, as compared to local government capacity, decentralization of revenue generation may not be effective. In 
Brazil, the enormous debt of state government banks has prompted the central bank to maintain control (Wilson and Graham, 1997). In countries with strong clientelistic traditions, the timely transfer of funds from national government to lower levels, as required in a truly decentralized system, is problematic in that it requires fundamental change in wellestablished political systems.

Decentralization generally implies the enhancement of the fiscal situation of local governments, especially in terms of creating opportunities for generating revenues locally. Although local decisionmaking and local control of own-source revenues are sound principles, the capacity to administer local tax systems may be absent and tax collection and new taxes may represent a political problem for local officials. Furthermore, the tax base in poor regions may be severely limited. From a national perspective, fiscal decentralization, especially in terms of greater local fiscal independence, will likely place poor regions at a substantial disadvantage in comparison to more wealthy regions (Wilson and Graham, 1997).

Another challenge to decentralized government is the growing importance of interorganizational relations (Radin et al., 1996). Given the trend toward less hierarchical governmental structures, cooperation among government agencies, or between agencies and nongovernmental organizations, in the performance of a single task increases. Organizations must become adept at cooperating and undertaking tasks as an element in a network of organizations. For most centralized governmental bureaucracies, this requires substantial reform from within.

\section{Linking the citizen and local government}

Having examined the organization of civil society and the capacity of the local government to act, attention can now return to the relationship of these two elements in determining the actions of government. This relationship can be quite complex, affected by formal institutional mechanisms as well as by informal ones. To further complicate our analysis, the role and importance of these mechanisms vary across countries. To structure our discussion, this relationship will be considered in three dimensions: the election of governing bodies, decisionmaking for government action (policymaking) and the process of implementation of policy decisions. ${ }^{4}$

Some argue that citizen involvement in government should be largely limited to the election of representatives, who conduct the affairs of government and whose actions can be held in account in later elections. However, it is now broadly recognized that government action is, and should be, subject to citizen influence throughout the policy process. The policymaking phase of the process contains two elements: the consideration of competing alternatives to address an issue and the

\section{Decentralization is seen as a way to make government smaller and more effective and promote democratic practice.}

decision, taken by the governing body, to pursue some specific action. In the implementation phase, government agencies or contracted organizations implement the programs or initiatives that follow from the policy decisions.

In democratic systems, in which political equality among individuals is a core value, the participation in elections of public officials is a principal means by which a civil society can influence government. In other words, citizens in democratic systems have the right to elect the officials who will determine what government is to do. Elected officials are held accountable to citizens by having to stand for election on a regular basis. Officials will convey, in theory, the interests and desires of their constituencies into the legislative arena where policy can be formulated. Elected officials not representing constituencies satisfactorily will presumably not be returned to office.

The imposition of free and fair election systems in democratizing countries is a prerequisite for improving governance. Shoring up the democratic floor is an essential component, especially in terms of the expansion of the political franchise to groups previously 
excluded (Fox, 1996, p. 12-13). But gaining the vote does not necessarily lead to minority representation among elected officials. In a number of countries, alternative elections schemes have been constructed to insure the representation of excluded groups among elected officials. India has taken the bold step of reserving a share of seats in local governing bodies for women, a group that historically has had quite limited influence on government (Mathew, 1996, p. 247-56). In some areas of the United States, cumulative voting systems to insure representation of underrepresented groups have been adopted.

In practice, the principles of democratic elections can be violated in many ways, including patronage and clientelism, which are found in many countries. Fair and free elections may best be thought of as a goal and countries should develop systems to monitor elections. But even fair election systems and inclusive political franchise do not necessarily secure the effective participation of citizens in the decisions concerning government action. A procedural democracy can be achieved without true participation of citizens. Without the articulation of the needs and desires of society and their incorporation in the political process, participation of civil society is incomplete. One visible element of this articulation is the presence of citizen deliberation in public forums or spaces. Such processes, called "strong democratic talks" by Benjamin Barber, are seen as the essence of political participation (Barber, 1984). A weakly organized civil society does not offer opportunities for such talks, which undermines democratic politics and forces government to take action without civil society advice (Wolfe, 1989). Civil society must be fully and fairly engaged in electing governing bodies, but must also be present in the process of defining and deciding upon the actions government should take.

Redemocratization and the expansion of policymaking at the local level, key elements of decentralization, pose interesting challenges for public deliberations. The ability of local government to serve as a venue for articulation and reconciliation of legitimate interests and consensus building is problematic in many countries. Under democratic regimes, with citizens able to exercise a role in public deliberations, a greater range of interests will likely be represented, thus increasing the likelihood of conflict. Contestation of ideas and interests should be embraced as a fundamental feature of democratic practice, but it complicates government action (Graham, 1995). For action to occur, interests must be articulated and when interests conflict, they must be reconciled. Although the assignment of formal responsibilities varies among countries, local governments are increasingly encouraged to serve as a forum or venue for policy debates, to reconcile differences and reach consensus on action. If this is a new role for a local government, the capacity for incorporating more open and flexible political processes must be generated. Once the capacity has been developed, however, challenges still remain. A reconciliation of interests at one point may not be sustained over time. A well established finding in the study of public policy is that electoral transitions frequently produce changes in policy, even in cases where the same political party retains control (Jacobi and Morales, 1996). Sustained and consistent governmental action is problematic under democratic regimes. Decentralization heightens this problem for local government.

At this point, the work of Robert Putnam (1993, Chapters 4 and 6) in Italy can be revisited. Putnam, in his historical analysis of regional government performance, found high performance to be positively correlated with the degree of organization in civil society or social capital. Greater numbers of civil society associations provided the opportunity for the desires of society to be articulated and expectations on government practice established.

Citizen participation in policymaking can take many different forms. Participation can occur in public hearings when individuals and groups consult with public officials. Through public protests and social movements, groups can communicate with officials and the broader public even when their message may be resisted. Another form of citizen involvement occurs when officials or outcomes of agencies and programs are scrutinized and compared against previous established goals. An independent, local press can facilitate this type of public accountability. In yet another form, political resources can be mobilized by groups for the purpose of placing issues on the public agenda and securing the adoption of specific policies 
(Wilson, 1997). For many issues, such as environmental policy, groups must acquire technical resources and expertise to be effective in the agenda setting process.

Citizen participation can also occur as policy is implemented. Often the policy decisions taken by legislative bodies leave much discretion to implementing agencies in terms of the specific actions to be undertaken. Decisions concerning siting of facilities or infrastructure investments may rest in the hands of administrative officials. Administrative officials may be hidden from public view and scrutiny and may be subject to class or ethnic biases that lead to actions inconsistent with the broader public will and, perhaps, even inconsistent with the elected governing body. This issue has great importance when considering local government. In many countries, local governments have responsibility for actions that affect property values. Decisions on the location of infrastructure investments can result in great windfalls to private interests. When local governments award franchises or regulate businesses, the possibilities for graft and corruption are high. Public involvement in and monitoring of government practices, which may establish the legitimacy of government action, are essential for democratic practice.

The participation of civil society in implementation also occurs through direct service provision by nongovernmental organizations. When local governmental capacity is weak or local populations require special consideration, nongovernmental organizations can be very effective. In Bangladesh, for example, nongovernmental organizations substitute for nonexistent government.

Governments in many countries have adopted policies, such as improving election systems, to induce citizen participation. In the United States, community participation provisions exist for many federal programs (Howard, Lipsky, Marshall, 1994). In Brazil, the Constitution of 1988 incorporates a variety of public councils - for health, children, the environment and others - to create forums for citizen participation. In spite of great potential, these councils face various challenges in practice. Council members may not have the experience or resources to participate fully. The service providers, because of their expertise and interests, can come to dominate councils. Some councils have become bureaucratized, which limits their effectiveness as channels for citizen participation (Wilson and Graham, 1991, section II). Government policy can enable participation, but its ability to generate participation may be limited. The full utilization of such mechanisms depends on the degree of political organization in the society.

\section{In countries like Mexico, Brazil, and India, local governments, lacking adequate financial, human, and institutional resources, have frequently not been prepared to assume the new responsibilities required by decentralization.}

Decentralization of policymaking provides the potential for greater citizen participation but it also runs a risk. Devolution of decisionmaking to local levels may provide traditional, nondemocratic elite the means to regain political domination. In addition citizens, as a result of past experience, may have no expectations for local government to perform well. In this context, a new political culture will need to be created before governance becomes meaningful.

\section{Challenges to improving governance}

Governance remains an alien concept in many developing countries. Many view the concept as an imposition of international agencies and western, industrialized countries. Nevertheless, the attention being given to governance should be welcomed. Despite the lack of consensus, the concept encourages the focus of development and government practice to expand beyond government itself. By broadening the context of governmental action, it tends to emphasize responsiveness of government to citizens and to improving 
government through stronger mechanisms of accountability. Nevertheless, caution must be exercised in the application of governance to particular country and cultural contexts. As a result of these considerations, governance can best be used as a diagnostic rather than a set of normative propositions.

Improving the effectiveness of government action, especially in terms of the improvement of living conditions in a country, remains the core concern. The responsibilities of local government vary substantially across countries and within a single country performance must be evaluated against the responsibilities and competencies that local governments hold. As others have suggested, governance should be conceptualized as the relationship between civil society and the public sector as it affects governmental action. This definition and understanding of governance can make an important contribution to the diagnosis of government action in a particular country or area.

In this framework, inadequate performance of local government can result from a number of sources. The problem may be in the public sector itself, which may have inadequate local capacity or will to act or be severely constrained by its intergovernmental context. Another potential source of difficulty is civil society, which may not be able to articulate interests and demands in an effective manner. Or inadequate performance may result from the relationship between the public sector and civil society. Citizens may not be able to participate fully and freely in the election of their leaders or there not may be a public space in which the interests of society are debated, aggregated and heard by public officials. Perhaps channels of communication between the two sectors are available but the public has inadequate knowledge of governmental action or understanding of the issues involved.

The analysis of poor performance in this framework leads to multiple strategies for enhancing performance. And substantial variation among countries regarding the most appropriate strategies should be expected. For example, a change in political culture so that citizens develop expectations concerning government performance or better electoral systems may be needed. Better information, socalled transparency, concerning governmental procedures, planning, and actions may be required. The creation of mechanisms that allow for the direct participation of civil society in determining governmental action may enhance performance.

Can experiences in one locale be successfully replicated in others? Although community participation can produce positive results on issues in a particular place, how can local action overcome the obstacle of being local? Can localities unite or associate in ways that lead to the adoption of enabling mechanisms at national government level? Can cross-fertilization of effective practice across local governments influence governance practices at the national level? Promoting participation across local governments and insuring that local participation can be aggregated to affect higher levels of government are mechanisms for overcoming the limitations of local action. One would hope that success in community and citizen participation in specific locales could eventually be broadly incorporated into a country's practice and even affect its political culture. Finally, what opportunities and constraints do national governments place on local governance? Improved local governance may be achieved through initiatives of higher levels of government. However, diffusion of innovative practice across local governments or local governments acting in coalition may also improve the prospects of local government performance.

The burden and responsibility this conception of governance places on civil society should not be underestimated. Effective government action is a responsibility civil society shares with government itself. A variety of governmental prerogatives and responsibilities, including the protection of basic human rights and the creation of contexts for citizen participation, exists in all societies but society must organize itself. The development of social capital is, in the end, a responsibility and function of civil society. If the unorganized and disenfranchised are also poor, the challenge is even greater. In some extreme cases, with widespread poverty, a complete lack of government institutions makes local governance moot. The argument that governance must be improved in order to improve governmental performance has much merit, but it must be applied with caution. It some situations, effective leadership, public and private, may be necessary before broad participation in public life can be 
achieved. If citizens have historically held no expectations of governmental action, without even some simple examples of government accomplishment, public expectations of improvement will not materialize. Even when the channels of participation are open and accessible, the information and analysis needed for coherent policy formation are substantial. In order for citizens to acquire such independent analysis, they will need considerable resources. This conception of governance identifies civil society as an essential factor for producing good government, but it also implies that only well organized and politically active societies have the ability to hold governments accountable. $O$
REFERENCES

ADVISORY COMMISSION ON INTERGOVERNMENTAL RELATIONS. Regulatory Federalism: policy, process, impact and reform. Washington, DC : Advisory Commission on Intergovernmental Relations, 1984.

APPROACHES to the enhancement of government capacity and performance: panel IV. In: WILSON, Robert H., CRAMER, Reid (Eds.). International workshop in governance. Austin, TX: LBJ School of Public Affairs, 1997. p. $59-70$

BARBER, Benjamin. Strong democracy: participatory politics for a new age. Berkeley, CA : University of California Press, 1984.

COLEMAN, James. Foundations of social theory. Cambridge, Mass : Harvard University Press, 1990. p. 300-321.

DAHL, Robert A. Democracy and its critics. New Haven : Yale University Press, 1989.

FOX, Jonathan. Local governance and citizen participation. In: WILSON, Robert H. CRAMER, Reid (Eds.). International workshop on local governance: second annual proceedings. Austin, TX: LBJ School of Public Affairs, 1996. p. 11-18.

GRAHAM, Larry. Summation of the issues and criteria in identifying good local government. In: WILSON, Robert H., CRAMER, Reid (Eds.). International workshop on good local government: first annual proceedings. Austin, TX: LBJ School of Public Affairs, 1995. p. 151-53.

LEFTWICH, Adrian. Governance, democracy and development in the Third World. Third World Quarterly: Journal of Emerging Areas, v. 14, n. 3, p. 610-12, 1993.

HALFANI, Mohamed. The challenge of urban governance in East Africa: responding to an unrelenting crisis. In: MCCARNEY, Patricia L. (Ed.). Cities and governance: new directions in Latin America, Asia and Africa. Toronto : Centre for Urban and Community Studies, 1996. p. 183-186.

HOWARD, Christopher, LIPSKY Michael, MARSHALL, Dale Rogers. Citizen participation in urban politics: rise and routinization. In: PETERSON, George E. (Ed.). Big city politics, governance, and fiscal constraints. Washington, DC : The Urban Institute Press, 1994. p. 153-199.

HYDEN, Goran. Governance and the study of politics. In: HYDEN, Goran, BRATTON, Michael (Eds.) Governance and politics in Africa. Boulder, Co. : Lynne Rienner, 1992. p. 5-8.
JACOBI, Pedro, MORALES, Carlos. Public policies and governability: policy continuity and disruption in the administration of collective transport in Santos, 198995. In: WILSON, Robert H., CRAMER, Reid (Eds.). International workshop on local governance: second annual proceedings. Austin, TX : LBJ School of Public Affairs, 1996. p. 29-46.

LANDY, Marc. Public policy and citizenship. In: INGRAM, Helen, SMITH, Steven Rathgeb. Public policy for democracy. Washington, DC : Brookings Institution, 1993. p. 19-44.

MATHEW, George. Local government and the empowerment of women. In: WILSON, Robert $\mathrm{H}$, CRAMER, Reid (Eds.). International workshop on local governance: second annual proceedings. Austin, TX LBJ School of Public Affairs, 1996. p. 247-256.

MCCARNEY, Patricia L. Considerations on the notion of governance. In: MCCARNEY, Patricia L. (Ed.). Cities and governance: new directions in Latin America, Asia and Africa. Toronto : Centre for Urban and Community Studies, 1996. p. 4-6.

MCCARNEY, Patricia L., HALFANI, Mohammed RODRIGUEZ, A. Towards an understanding of governance: the emergence of an idea and its implications for urban research in developing countries. In: STREN, Richard (Ed.). Urban research in developing countries. Toronto : Centre for Urban and Community Studies, University of Toronto, 1995 v. 4 , p. $95-98$

PORIO, Emma. Urban governance in Southeast Asia: implications for sustainable human settlements. In: MCCARNEY, Patricia L. (Ed.). Cities and governance: new directions in Latin America, Asia and Africa. Toronto : Centre for Urban and Community Studies, 1996. p.75.

PUTNAM, Robert D. Making democracy work Princeton, NJ : Princeton University Press, 1993.

RADIN, Beryl et al. New governance for rural America: creating intergovernmental partnerships. Lawrence, KS : University of Kansas Press, 1996. Chapter 5.

SKCOPOL, Theda. Bring the state back in: strategies of analysis in current research. In: EVANS, Peter, RUESCHEMEYER, Dietrich, SKOCPOL, Theda (Eds.) Bringing the state back in. New York : Cambridge University Press, 1985. p. 3-37.
STEPAN, Alfred. The state and society: Peru in comparative perspective. Princeton, NJ : Princeton University Press, 1978. p. xii.

TAYLOR, Charles. Modes of civil society. Public Culture, V. III, p. 95-107, 1990.

TOCQUEVILLE, Alexis de. Democracy in America. New York : Harper \& Row, 1966

URBAN research in the developing world. A four volume series, edited by Richard Stren. Toronto : Centre for Urban and Community Studies. vol. 1-Asia, 1994; vol. 2 - Africa, 1994; vol. 3 - Latin America, 1995; and vol. 4 - Perspectives on the City, 1995.

WILSON, Robert H. (Ed.). Public policy and community: activism and governance in Texas. Austin, TX: University of Texas Press, 1997. Chapter 9.

WILSON, Robert $\mathrm{H}$. Is devolution approaching its limits? Austin, TX: LBJ School of Public Affairs, 1998. (Working Paper, n. 87).

WILSON, Robert H., GRAHAM, Lawrence (Eds.) Policymaking in a redemocratized Brazil. Austin, TX : LBJ School of Public Affairs, 1997. Vol. 1: Decentralization and social policy.

WILSON, Robert H., GRAHAM, Lawrence (Eds.) Policymaking in a redemocratized Brazil. Austin, TX : LBJ School of Public Affairs, 1997. Vol. 2: Public policy and social exclusions, n. 119.

WOLFE, Alan. Whose keeper: social science and moral obligation. Berkeley : University of California Press, 1989

WORLD BANK. Sub-Saharan Africa: from crisis to sustainable growth: a long term perspective. Washington, DC : The World Bank, 1989.

WORLD BANK. Governance and development Washington, DC : The World Bank, 1992. p. 3.

WORLD BANK Governance: the World Bank's experience. Washington, DC : The World Bank, 1994.

ZICCARDI, Alicia. Governance and governability: one or two concepts. In: WILSON, Robert H., CRAMER, Reid (Eds.). International workshop on good local government. Austin, TX : LBJ School of Public Affairs, 1995. p. 78-83.

\section{NOTES}

1. Legitimacy itself is connected to governance. Hyden argues that four variables are prerequisites for effective governance, trust, reciprocity, accountability, and authority, can also be used to measure regime legitimacy. See Hyden, 1992, p. 12-15.

2. A group of writers holding this view is discussed in COLE, Richard L. Citizen participation and the urban policy process. Lexington, MA : Lexington Books,
1974. p. 2-4. See also BERGER, Peter L., NEUHAUS Richard J. To empower people: the role of mediating structures in public policy. Washington : American Enterprise Institute, 1977.

3. For a discussion of one organization's strategy fo developing social capital, see CORTES, Ernesto. Reweaving the fabric: the iron rule and the IAF strategy for power and politics. In: CISNEROS, Henry G. (Ed.). Interwoven destinies: cities and the nation. New York :WW Norton, 1993. p. 294-319.

4. The assumption is that local government does have decisionmaking responsibility for government action. If it does not, local governance cannot exist in a meaningful sense, as discussed above in relationship to the capacity of local government. 